\title{
Konsep dan Strategi Komunikasi Pemasaran: Perubahan Perilaku Konsumen
}

\section{Menuju Era Disrupsi}

\author{
Dea Farahdiba \\ Mahasiswa Magister Sains Manajemen, Universitas Gadjah Mada \\ e-mail: dea.farahdiba@mail.ugm.ac.id
}

\begin{abstract}
ABSTRAK
Pemasaran telah berkembang dari konsep pemasaran 1,0 menuju 4,0 sehingga untuk mempelajari apa yang dibutuhkan dan diinginkan konsumen maka pemasar harus mampu memiliki kebijakan dengan menggunakan komunikasi yang tepat agar berbagai informasi tentang produk dapat ditransfer ke konsumen. Untuk itu perlu lebih memahami komunikasi, terutama komunikasi pemasaran dalam hal membentuk perilaku konsumen. Tujuan dari artikel ini adalah untuk memberikan wawasan dalam bidang komunikasi pemasaran. Metodologi penelitian ini merupakan studi literatur dari beberapa jurnal yang membahas mengenai komunikasi pemasaran. Keberadaan komunikasi dapat memudahkan seseorang untuk berinteraksi antara satu individu dengan individu lainnya. Tanpa adanya komunikasi maka tidak ada proses kehidupan manusia. Artinya, setiap manusia membutuhkan komunikasi untuk bertukar gagasan guna mewujudkan apa yang diinginkannya. Tiga pergeseran pemasaran utama, ditandai dengan pemasaran yang digerakkan oleh produk dalam era 1,0 selanjutnya menuju pemasaran yang berpusat pada pelanggan dalam era 2,0. Pemasaran yang berpusat pada manusia ada di era 3,0. Di sisi lain, alat-alat komunikasi pemasaran bisa berupa iklan, tenaga penjualan, papan nama, toko, display, kemasan produk, sampel produk gratis, kupon, hadiah dan lainnya. Adapun perubahan perilaku konsumen yang semakin berkembang, dampak dari pemasaran 4,0 juga menghasilkan adanya pemasaran viral melalui jejaring sosial seperti Facebook memungkinkan interaktivitas dua arah secara terus-menerus dari mana saja dan kapan saja.
\end{abstract}

Kata kunci : Komunikasi Pemasaran, Pemasaran, Perilaku Konsumen.

\section{ABSTRACT}

Marketing has evolved from the concept of marketing 1.0 to 4.0 so that to learn what is needed and wanted by consumers, marketers must be able to have policies using appropriate communication so that various information about products can be transferred to consumers. For this reason, it is necessary to better understand communication, especially marketing communication in terms of shaping consumer behavior. The purpose of this article is to provide insight in the field of marketing communication. This research methodology is a literature study from several journals that discusses marketing communication. The existence of communication can make it easier for someone to interact between one individual with another individual. Without communication there is no human life process. That is, every human being needs communication to exchange ideas in order to realize what he wants. Three major marketing shifts, marked by product-driven marketing in the later 1.0 era towards customer-centered marketing in the 2.0 era. Human-centered marketing existed in 
the 3.0 era. On the other hand, marketing communication tools can be in the form of advertisements, sales, signage, shops, displays, packaging, free product samples, coupons, giveaway and more. As for changing consumer behavior that is increasingly developing, the impact of marketing 4.0 also results in viral marketing through social networks such as Facebook enabling continuous two-way interactivity from anywhere and at any time.

Keywords: Marketing Communication, Marketing, Consumer Behavior.

\section{Pendahuluan}

Meningkatnya persaingan minat pemasar dalam memahami perilaku konsumen telah menjadi isu sentral dan salah satu bidang penelitian yang paling menantang dan menarik (Gupta 2016, 225). Mohir, Webb, dan Harris, (2001), mengemukakan bahwa sebuah pertanyaan utama untuk bisnis secara historis adalah apakah para pembuat keputusan perusahaan harus peduli dengan masalah selain keuntungan perusahaan saja. Manajemen perusahaan harus benar-benar memiliki strategi bisnis untuk mencapai tujuan perusahan dengan baik dan benar. Pemasaran adalah suatu sistem keseluruhan dari kegiatan-kegiatan bisnis yang ditujukan untuk merencanakan, menentukan harga, mempromosikan, dan mendistribusikan barang dan jasa yang memuaskan kebutuhan baik kepada pembeli yang ada maupun pembeli potensial (Swastha dan Irawan 2008, 5). Pemasaran merupakan bagian dari ujung tombak yang menjadikan suatu perusahaan akan meraih kesuksesan atau kemunduran. Manajer pemasaran mempunyai tugas utama, yaitu menjual produk atau jasa dari suatu perusahaan yang mempunyai target pasar sesuai dengan yang telah ditentukan oleh perusahaan. Pemasaran memiliki kiprah dan perjalanan yang telah berevolusi dari pemasaran 1,0 sampai pada konsep pemasaran 4,0.

Perlu diketahui juga konsumen adalah titik sentral perhatian pemasaran, sehingga untuk mempelajari apa yang dibutuhkan dan diinginkan konsumen ini adalah hal yang sangat penting. Memahami konsumen akan menuntun pemasar ke arah kebijakan pemasaran yang tepat, dan melalui komunikasi, serta berbagai informasi mengenai produk dapat ditransfer ke konsumen. Untuk itu diperlukan pemahaman yang lebih mengenai komunikasi, terutama komunikasi pemasaran dalam kaitannya membentuk perilaku konsumen. Adanya interaksi antara satu pihak dengan pihak lain biasanya menjalin sebuah komunikasi. Komunikasi bisa dilakukan oleh berbagai pihak maupun golongan, tak kenal usia maupun jenis kelamin.

Sebagai seorang pemasar sebaiknya harus mengetahui keinginan dan kebutuhan konsumen dari berbagai aspek yakni persepsi, gaya hidup, sikap, budaya, kelas sosial, kelompok rujukan, keluarga dan komunikasinya. Informasi yang diterima konsumen melalui komunikasi memainkan peranan penting untuk bisa diserap oleh para pemasar dalam memahami strategi dan konsep komunikasi pemasaran melalui perilaku konsumen. Komunikasi pemasaran adalah sarana yang digunakan perusahaan untuk memberi informasi, membujuk, dan mengingatkan konsumen secara langsung atau tidak langsung tentang produk dan merek yang mereka jual (Kotler \& Keller, 2016, hal. 580). Adapun dukungan publik 
tentang komunikasi pemasaran terintegrasi ini percaya bahwa kemunculannya lebih cenderung ke konteks media seperti TV digital dan telepon seluler, serta lingkungan pasar yakni meningkatnya persaingan global dan perkembangan teknologi yang cepat (Kitchen dan Burgmann, 2010).

Dalam sebuah komunikasi tidaklah semulus yang dibayangkan, ada sejumlah kendala yang akan mempengaruhi keberhasilan sebuah proses komunikasi. Hal itu bisa saja mencakup sebuah pesan yang disampaikan dapat dartikan secara berbeda sehingga menimbulkan efek dan tindakan yang berbeda pula. Selain dari sisi pesan, hambatan dan gangguan komunikasi bisa berasal dari komunikator, komunikan, juga pemilihan media. Untuk itu diperlukan pemahaman yang lebih mengenai komunikasi, terutama komunikasi pemasaran dalam kaitannya membentuk perilaku konsumen, dimana saat ini hampir semua organisasi, baik perusahaan bisnis maupun nirlaba, juga usaha individu menggunakan berbagai bentuk komunikasi pemasaran untuk mempromosikan apa yang mereka tawarkan demi mencapai tujuan perusahaan,dan juga agar konsumen dapat bersikap dan berperilaku sesuai dengan yang diharapkan.

Selain itu, perlunya mempelajari komunikasi pemasaran dalam kaitannya memahami serta membentuk perilaku konsumen, pemasar juga harus paham betul tentang kondisi pasar saat ini yang bisa dibilang sudah memasuki era transisi dari tradisional ke era digital. Perekonomian dunia, khususnya negara-negara berkembang seperti Indonesia, sedang bergerak menuju ekonomi digital. Perkembangan teknologi menjadi penggerak pertama perubahan tersebut. Organisasi dunia OECD (Organization for Economic Cooperation and Development) menyatakan, inovasi digital diklaim mampu membawa banyak negara lebih dekat pada kemakmuran yang berkesinambungan (Xie, Shang, Yang, dan Yi, 2014). Teknologi membantu mengembangkan sektor-sektor ekonomi, seperti sektor ritel dengan e-commerce, transportasi dengan kendaraan automatis, pendidikan dengan aneka kursus online, kesehatan, sampai interaksi sosial melalui media sosial (Xie, Shang, Yang, dan Yi, 2014). Teknologi tidak hanya dapat membantu konsumen untuk terhubung dan berkomunikasi satu sama lain tetapi juga dapat bertindak sebagai fasilitator dalam membangun hubungan dengan konsumen individu dan perusahaan.

Penelitian yang dilakukan oleh Pavenkov dan Rubtcova (2019), membahas mengenai komparatif dari model tradisional komunikasi pemasaran dan model baru komunikasi pemasaran terpadu. Penelitian tersebut juga fokus pada ketentuan utama komunikasi pemasaran terintegrasi dan perbedaan antara model tradisional komunikasi pemasaran dari komunikasi pemasaran terpadu. Hasilnya menjelaskan bahwa komunikasi pemasaran terpadu sebagai pendekatan baru memecahkan masalah lama dari pendekatan tradisional. Hal itu memungkinkan untuk menghilangkan efek dari pengiriman berbagai pesan yang kontradiktif tentang produk kepada perusahaan.

Artikel ini merupakan tinjauan literatur yang bertujuan untuk menemukan konsep dan strategi komunikasi pemasaran terkait perubahan perilaku konsumen menuju era disrupsi. Untuk keperluan tersebut dibutuhkan adanya pendekatan pemasaran baru guna membantu pemasar dalam mengantisipasi dan mengelola dampak teknologi yang disruptif tersebut. Oleh karena itu, konsep dan strategi komunikasi pemasaran dalam kaitannya untuk 
memahami perilaku konsumen menuju era disrupsi ini sangat perlu diulas agar dapat memberikan pemahaman yang lebih luas.

\section{Kajian Pustaka}

\section{a. Pengertian dan Model Perilaku Konsumen}

Perilaku konsumen (consumer behavior) didefinisikan sebagai kegiatan-kegiatan individu yang secara langsung terlibat dalam mendapatkan dan mempergunakan barang-barang dan jasa-jasa, termasuk di dalamnya proses pengambilan keputusan pada persiapan dan penentuan kegiatan-kegiatan tersebut (Dharmesta dan Handoko 2016, 10). Perilaku konsumen juga didefinisikan sebagai proses pengambilan keputusan dan aktivitas individu secara fisik yang dilibatkan dalam proses mengevaluasi, memperoleh, menggunakan, atau dapat mempergunakan barang-barang dan jasa (Loudon dan Bitta, 1993). Sebenarnya, tidak ada teori perilaku konsumen yang diakui secara umum karena masing-masing memiliki pengetahuan khusus dan hanya dapat diterapkan situasi yang berbeda (Dharmesta dan Handoko 2016, 27).

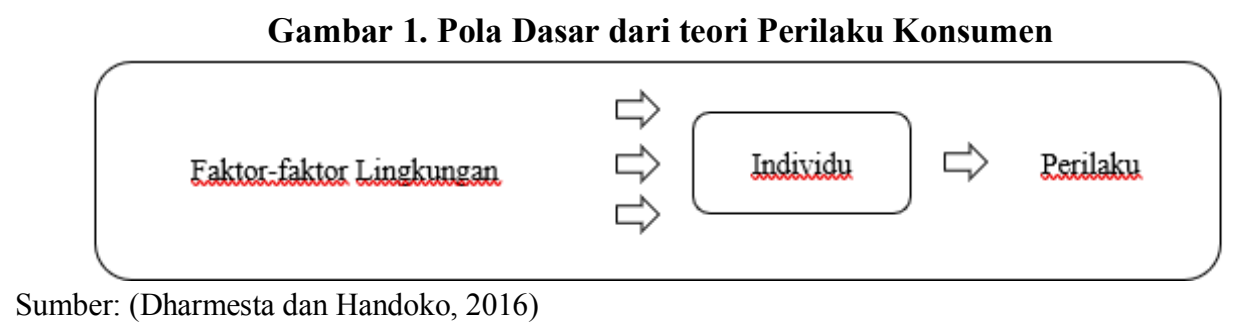

Gambar 1. menjelaskan mengenai pola dasar dari teori perilaku konsumen bahwa perilaku konsumen itu muncul atas adanya beberapa bentuk interaksi antara faktor-faktor lingkungan disatu pihak, dan individu di lain pihak. Masalah utama dari perspektif perilaku konsumen adalah sejauh mana objek yang dimiliki melayani fungsi mendefinisikan dan mempertahankan konsep diri atau identitas konsumen (Ball dan Tasaki, 1992). Penting juga dipahami oleh seorang pemasar bahwa perilaku konsumen berbeda-beda, karena setiap individu memiliki sifat yang berbeda-beda pula. Setiap konsumen pastinya memiliki kebutuhan dan keinginan untuk memuaskan diri sendiri. Kebutuhan konsumen adalah suatu kesenjangan atau pertentangan yang dialami antara suatu kenyataan dengan dorongan yang ada dalam diri (Mangkunegara, 2015). Dalam pemenuhan suatu kebutuhan yang diinginkan oleh setiap konsumen pastinya ada rasa kecewa tersendiri yang muncul pada dalam diri jika suatu kebutuhan tersebut tidak bisa terpenuhi. Namun, berbanding terbalik jika pemenuhan kebutuhan itu dapat terpenuhi pastinya muncul perilaku gembira dan rasa puas dalam diri. Dalam memenuhi kebutuhan, manajemen pemasaran harus menentukan basic needs dari konsumen, sedangkan dalam memenuhi keinginan harus menentukan basic wants dari konsumen (Dharmesta dan Handoko 2016, 25).

Masalah awal manajemen pemasaran mempelajari model perilaku konsumen adalah untuk menyelidiki rasionalitas perilaku konsumen, dalam upaya untuk 
menunjukkan bahwa lebih banyak konsumen berpikir mereka senang dengan sebuah informasi atau komunikasi yang diberikan oleh produk atau penjual terhadap barang yang diinginkan konsumen itu jelas dan detail. Agar bisa dibandingkan dengan produk lainnya. Hal ini bisa ditarik kesimpulan bahwa perilaku konsumen memang dibentuk dengan adanya sebuah stimuli yang diberikan dari berbagai aspek. Adapun beberapa faktor lainnya yang mempengaruhi perilaku konsumen untuk mengambil keputusan membeli.

Gambar 2. Model Perilaku Konsumen dari Howard dan Sheth

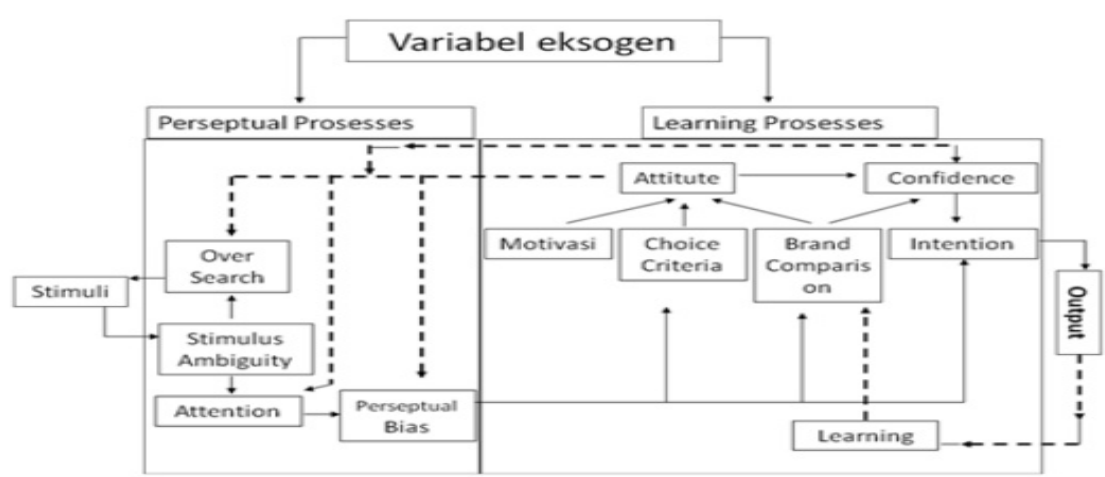

Sumber: (Howard dan Sheth, 1967)

Variabel eksogen dari gambar 2. model perilaku konsumen Howard dan Sheth terdiri dari proses pengamatan dan proses belajar. Proses pengamatan itu sendiri terdiri dari perhatian, stimulus ambiguitas, dan bias persepsi. Sedangkan, proses belajar terdiri dari motif, kriteria memilih, pemahaman merek, sikap, niat, kepercayaan, dan kepuasan. Konsumen untuk melakukan pembelian suatu produk diawali dengan adanya kesadaran atas pemenuhan kebutuhan dan keinginan. Setelah itu jika sudah disadari adanya kebutuhan dan keinginan, maka konsumen akan mencari informasi mengenai keberadaan produk yang diinginkannya. Dari berbagai informasi yang diperoleh, konsumen melakukan seleksi atas alternatif-alternatif yang tersedia. Sesudah melakukan proses seleksi, dengan berbagai kriteria yang ada dalam benak konsumen, salah satu produk akan dibeli. Dengan dibelinya suatu produk tertentu, proses perilaku konsumen belum berakhir karena konsumen akan melakukan evaluasi pasca pembelian. Proses evaluasi ini akan menentukan apakah konsumen merasa puas atau tidak, jika puas maka ada kemungkinan untuk terus melakukan pemeblian di masa depan, tapi jika tidak puas kemungkinan di masa depan mereka akan mencari lagi berbagai informasi produk yang dibutuhkannya.

\section{b. Pengertian dan Konsep Komunikasi Pemasaran}

Komunikasi pemasaran dapat dipahami dengan menguraikan dua unsur pokoknya, yaitu komunikasi dan pemasaran. Komunikasi secara sederhana diartikan sebagai proses penyampaian pesan dari sumber ke penerima. Sebuah definisi tentang komunikasi juga dipaparkan oleh Carl I. Hovland yakni komunikasi sebagai sebuah proses yang memungkinkan seseorang (komunikator) untuk dapat menyampaikan 
rangsangan, dengan tujuan untuk dapat mengubah prilaku orang lain (komunikan). Adapun definisi komunikasi dari Harold D Lasswell bahwa cara yang tepat untuk menerangkan suatu tindakan komunikasi ialah menjawab pertanyaan "siapa yang menyampaikan, apa yang disampaikan, melalui saluran apa, kepada siapa dan apa pengaruhnya" (Komala, 2009). Adanya komunikasi dapat memudahkan seseorang

untuk berinteraksi antar satu individu dengan individu lain. Luasnya ruang lingkup kehidupan manusia pastinya dipenuhi dengan komunikasi, tanpa adanya sebuah komunikasi maka tidak ada proses kehidupan manusia. Artinya, setiap manusia membutuhkan komunikasi untuk saling bertukar pikiran untuk mewujudkan apa yang diinginkan.

Menurut Swastha dan Irawan (2008), sebagai dasar pengembangan kegiatan promosi yakni komunikasi, dalam bidang pemasaran tentunya komunikasi itu sangat penting. Komunikasi pemasaran merepresentasikan semua unsur dalam bauran pemasaran yang memfasilitasi terjadinya pertukaran dengan menciptakan suatu arti yang disebarluaskan kepada pelanggan atau kliennya (Shimp, 2000). Literatur pemasaran menunjukkan bahwa tujuan utama dari tindakan pemasaran adalah untuk membangun dan mempertahankan hubungan jangka panjang, menguntungkan dengan pelanggan serta untuk meningkatkan loyalitas pelanggan. Secara khusus, komunikasi pemasaran dan pemasaran basis data sangat penting untuk peningkatan loyalitas (Seric, Ozretic-Dosen, dan Skare, 2019). Proses komunikasi pemasaran pada hakikatnya merupakan suatu proses komunikasi, yaitu penyampaian pesan oleh sumber kepada penerima yang dilakukan melalui media tertentu. Ball, Simoes, dan Machas (2004, hal. 1277), mengatakan bahwa "komunikasi yang baik harus mempengaruhi semua aspek hubungan, tetapi sebagian besar mencakup kepercayaan, kepuasan dan loyalitas."

Kepercayaan konsumen terhadap sumber dipengaruhi oleh kredibilitasnya. Konsumen akan lebih percaya pada pemasar yang terbukti tidak mengobral janji dan bersifat obyektif, tidak menjelek-jelekkan pesaing dan menutupi kekurangannya. Biasanya konsumen lebih percaya terhadap sumber yang bersifat tidak formal seperti keluarga, sahabat, rekan keja, atau kerabat yang sudah pernah menggunakan produk tersebut. Biasanya sumber informal itu cenderung lebih obyektif, karena tidak memiliki kepentingan atas apa yang ingin disampaikan. Berbeda dengan sumber formal yang cenderung lebih berorientasi pada penjualan yakni agar produknya cepat laku. Seric, Ozretic-Dosen, dan Skare (2019) mengemukaan bahwa, sinergi komunikasi pemasaran berupaya menciptakan kesadaran merek dan memberikan pemahaman tentang atribut dan manfaat utama produk dan layanan. Kedua, komunikasi pemasaran berusaha membawa konsumen untuk membeli. Ketiga, komunikasi pemasaran bertujuan mendorong penggunaan produk atau layanan secara teratur, yaitu, mendapatkan pelanggan yang loyal. 


\section{c. Tujuan Komunikasi Pemasaran}

Komunikasi yang efektif dapat merubah tingkah-laku, atau memperkuat tingkahlaku yang sudah diubah sebelumnya (Swastha dan Irawan, 2008). Komunikasi pemasaran bertujuan untuk mencapai tiga tahap perubahan yang ditujukan kepada konsumen (Soemanagara, 2012). Menurut Soemanagara (2012), tahap-tahap tersebut antara lain:

1) Tahap perubahan pengetahuan (knowledge change), dalam perubahan ini konsumen mengetahui adanya sebuah produk, untuk apa produk itu diciptakan dan ditujukan kepada siapa produk tersebut, dengan demikian pesan yang disampaikan tidak lebih menunjukkan informasi penting sebuah produk.

2) Tahap kedua adalah tahap perubahan sikap, dalam perilaku konsumen yakni perubahan sikap ditentukan oleh tiga unsur, yang disebutkan oleh Schiffman dan Kanuk sebagai tiga komponen perubahan sikap yaitu pengetahuan, sikap dan perilaku. Perubahan sikap yang dikehendaki tentu saja perubahan sikap kearah yang positif, perubahan positif ini mengarah kepada keinginan konsumen untuk mencoba produk, semakin tinggi kesukaan pada suatu produk, maka akan mendorong konsumen untuk memakainya (membelinya).

3) Tahap ketiga yaitu perubahan perilaku yang ditujukan agar konsumen tidak beralih kepada produk lain dan terbiasa untuk terus memakainya. Pada tahap perubahan perilaku (behaviour change) pesan ditujukan untuk menunjukkan alasan alasan kenapa produk ini masih menjadi produk yang terbaik dibanding produk lainnya.

\section{d. Perubahan Perilaku Konsumen}

Perilaku konsumen mencakup proses pengambilan keputusan dan kegiatan yang dilakukan konsumen secara fisik dalam perolehan penggunaan atau mendapatkan barang dan jasa untuk dikonsumsi (Loudon dan Bitta, 1993). Perilaku konsumen adalah tindakan-tindakan, proses, dan hubungan sosial yang dilakukan individu, kelompok, dan organisasi dalam mendapatkan, menggunakan suatu produk atau lainnya sebagai suatu akibat dari pengalamannya dengan produk, pelayanan, dan sumber-sumber lainnya (Zaltman dan Wallendorf, 1979 dalam Mangkunegara, 2015). Di dalam mempelajari perilaku konsumen, pemasar tidak hanya berhenti pada perilaku konsumen semata saja namun juga perlu mengkaitkanya dengan strategi pemasaran yang akan disusun. Strategi pemasaran yang baik pada hakekatnya didasarkan pada apa yang diinginkan dan dibutuhkan konsumen. Perusahaan yang mampu memahami perilaku konsumen akan mendapatkan keuntungan yang cukup besar karena dapat menyusun strategi pemasaran yang tepat yang dapat memberikan kepuasan yang lebih baik dibandingkan dengan pesaingnya.

Perubahan lingkungan senantiasa terjadi terus-menerus dalam proses perkembangan suatu negara, yang secara langsung maupun tidak langsung, akan mempengaruhi kehidupan dan tata ekonominya, cara-cara pemasaran dan perilaku manusia-manusianya (Dharmesta dan Handoko 2016, 9). Banyak perubahan lingkungan yang sudah terjadi 
sampai saat ini dan menghasilkan berbagai revolusi, baik dari industri maupun revolusi pemasaran juga memberikan dampak yang beragam. Pada tahun ini 2019, sudah banyak kemudahaan yang terjadi di ruang lingkup masyarakat. Kemudahaan itu berasal dari kemajuan teknologi yang sangat pesat dan berdampak pada perilaku manusia sebagai konsumen. Dampak dari kemajuan teknologi juga bisa dilihat dari kebaharuan produkproduk yang dihasilkan oleh perusahaan yang sangat berinovasi. Contohnya saja kota

pelajar Yogyakarta, kini sudah banyak minuman yang dikenal dengan sebutan cheese tea. Sebuah inovasi dari teh dengan perpaduan cengkeh Thailand ditambah krim keju untuk diseduh. Tahun-tahun sebelum ini belum ada jenis minuman seperti itu namun karena efek pasar global yang sudah sangat banyak isu untuk dipelajari, maka timbul lah inovasi yang di ambil dari budaya di luar Indonesia untuk dijadikan peluang bisnis. Bahkan tidak hanya di bidang kuliner saja, inovasi sebuah produk juga tengah dirasakan oleh masyarakat sekitar. Maraknya kemunculan start-up GoJek dan Grab mempermudah transportasi seseorang.

Dengan adanya dampak dari revolusi industri ini, perilaku dan selera konsumen juga menunjukkan adanya perubahan. Perusahaan yang hidup dalam lingkungan dinamis haruslah selalu mengembangkan keahlian dan kemampuan dalam pemasarannya (Dharmesta dan Handoko 2016, 9). Suatu perusahaan yang hidup dalam lingkungan dinamis harus selalu mengembangkan keahlian dan kemampuan dalam pemasarannya. Lebih lanjut diungkapkan oleh Dharmesta dan Handoko (2016), perubahan lingkungan yang tercermin juga pada perubahan perilaku konsumen menyebabkan manajemen pemasaran dituntut untuk selalu memperbaharui pengenalan terhadap konsumennya, menilai kembali kebutuhan-kebutuhan mereka sekarang, dan juga memperkirakan kebutuhan konsumen di waktu yang akan datang.

Perubahan perilaku konsumen dalam bidang pemasaran juga bisa dibuktikan dengan sudah banyaknya yang berubah dari sistem komunikasi pemasaran. Di era pemasaran 4.0 saat ini yang ditunjukkan dengan mengkombinasikan interaksi online dan interaksi offline antara perusahaan dengan pelanggan. Perusahaan start-up yang berkembang dan memberikan pengaruh dari dampak pemasaran 4,0 ini dengan kemunculan Shopee, BukaLapak, Tokopedia, dan lain-lain. Sudah banyak wirausahawan berhasil dengan berjualan online melalui start-up tersebut. Saat ini sudah banyak pengguna online yang merasakan kemudahaan dalam berbelanja. Walaupun resiko yang muncul tentunya tidak bisa dihindari. Kemudahan yang dirasakan oleh konsumen dengan berbelanja online ini juga tidak lepas dari komunikasi pemasaran yang diberikan oleh perusahaan agar bisa sampai kepada konsumen, walaupun tidak berinteraksi langsung untuk bertemu, namun seorang pemasar harus bisa memahami bagaimana para konsumen sebagai pengguna online tetap dapat pelayanan yang memuaskan dan tidak beda jauh dari pada konsumen yang membeli barang di outlet 
atau dengan sistem offline.

\section{e. Era Disrupsi}

Kata disrupsi menjadi amat popular karena sejalan dengan muncul dan berkembangnya aplikasi-aplikasi teknologi informasi dan mengubah bentuk kewirausahaan biasa menjadi start-up (Kasali 2008, 149). Tiga pergeseran pemasaran utama, ditandai dengan product-driven marketing pada pemasaean 1,0 lalu menuju customer-centric marketing pada pemasaran 2,0, selanjutnya human-centric marketing pada pemasaran 3,0. Belakangan ini sudah banyak akademisi yang membahas tentang revolusi pemasaran 4,0 yang seiring dengan hadirnya revolusi industri 4,0 (Kotler, Kartajaya, dan Setiawan, 2016). Revolusi pemasaran ini merupakan pendekatan pemasaran yang mengkombinasikan interaksi online dan interaksi offline antara perusahaan dengan pelanggan.

Perilaku konsumen di era digital merupakan pendekatan pemasaran yang mengkombinasikan interaksi antara online dan offline. Artinya, merek tidak hanya mengedepankan branding yang bagus, tetapi juga konten yang relevan dengan pelanggan. Banyak subjek penelitian dalam beberapa tahun terakhir tentang perilaku konsumen di era digital, tetapi memahami hal itu dipersulit oleh fakta bahwa entitas utama yang terlibat, konsumen dan bisnis, telah berubah. Pertama, setiap konsumen sekarang juga adalah pengguna komputer. Konsumen online melakukan semua fungsi konsumen tradisional di komputer sambil berinteraksi dengan sistem, yakni situs web komersial. Menurut Koufaris (2014), karena itu, ia juga memperlihatkan semua karakteristik pengguna komputer. Kedua, toko fisik telah diubah menjadi toko virtual melalui teknologi informasi (TI). Dalam dunia komersial fisik, TI yang digunakan untuk operasi sebagian besar tetap berada di latar belakang, tidak terlihat oleh konsumen. Namun, dalam e-commerce, teknologi telah dipindahkan ke latar depan dan telah menjadi toko itu sendiri sebagai situs web (Koufaris, 2014).

\section{f. Peranan Komunikasi Pemasaran terhadap Pembentukan Perilaku Konsumen}

Dalam pengambilan keputusan konsumen, tentu saja informasi yang diterima konsumen melalui komunikasi memainkan peranan penting untuk membentuk persepsi konsumen yang akhirnya akan menghasilkan suatu perilaku yang dilakukan oleh konsumen. Komunikasi pemasaran berperan untuk menyampaikan pesan kepada publik terutama konsumen sasaran mengenai keberadaan produk di pasar. Di era digital, kontrol manajer pemasaran atas konten, waktu, dan frekuensi informasi sedang terkikis parah. Dalam paradigma baru, informasi tentang produk dan layanan juga berasal dari pasar. Informasi ini didasarkan pada pengalaman konsumen individu dan disalurkan melalui bauran promosi tradisional (Mangold dan Faulds, 2009). Namun, berbagai platform media sosial, yang banyak diantaranya sepenuhnya bersifat independen dari organisasi produsen atau sponsor atau agennya, memperbesar kemampuan konsumen untuk berkomunikasi satu sama lain. Dalam paradigma komunikasi baru, manajer 
pemasaran harus mengenali kekuatan dan sifat kritis dari diskusi yang dilakukan oleh konsumen menggunakan media sosial.

Konsep komunikasi pemasaran yang secara umum sering digunakan untuk menyampaikan pesan adalah apa yang disebut sebagai bauran promosi. Terdapat lima bauran promosi yaitu, iklan, penjualan tatap muka, promosi penjualan, publisitas, serta pemasaran langsung (Kotler dan Keller 2016, 47f). Menurut Swastha dan Irawan (2008), periklanan merupakan bentuk presentasi dan promosi non pribadi tentang ide, barang, dan jasa yang dibayar oleh sponsor tertentu. Dalam penentuan kegiatan periklanan, setiap perusahaan pastinya memikirkan beberapa keputusan yang harus diambil yakni menentukan piklan yang harus disampaikan kepada pasar yang dituju serta memilih media yang paling sesuai. Penjualan tatap muka merupakan interaksi tatap muka dengan satu atau lebih calon pembeli untuk tujuan membuat presentasi, menjawab pertanyaan, dan melakukan pemesanan (Kotler dan Keller 2016, hal. 582). Melalui penjualan tatap muka ini memiliki keunggulan dalam tingkat kesadaran konsumen yang lebih tinggi, yakni dapat menyampaikan pesan (menjelaskan produk) dengan lebih detail, dan yang paling penting penjualan tatap muka adalah untuk menciptakan penjualan. Penjualan tatap muka adalah satu satunya alat komunikasi yang digunakan secara langsung terhadap konsumen potensial.

Menurut Kotler dan Armstrong (2018), promosi penjualan merupakan insentif jangka pendek untuk mendorong uji coba atau pembelian produk atau layanan termasuk promosi konsumen (seperti sampel, kupon, dan premi), promosi perdagangan (seperti tunjangan iklan dan tampilan), dan promosi bisnis dan tenaga penjualan. Sedangkan, publisitas merupakan berita atau bentuk komunikasi pihak perusahaan yang tidak memiliki konten, baik itu positif maupun negatif. Konten pemasaran mampu menciptakan atau menyampaikan nilai-nilai dari produk tersebut. Dalam arti lain publisitas merupakan usaha-usaha untuk menciptakan dan mempertahankan hubungan yang menguntungkan antara organisasi dengan masyarakat, termasuk pemilik perusahaan, karyawan, lembaga pemerintah, penyalur, serta calon pembeli (Swastha dan Irawan 2008, hal. 352).

Pemasaran langsung merupakan sistem pemasaran dimana organisasi berkomunikasi secara langsung dengan target konsumen untuk menghasilkan respon atau terjadinya transaksi penjualan. Pemasaran langsung ini memanfaatkan beragam saluran untuk menjangkau prospek dan pelanggan. Beberapa perusahaan konsumen juga banyak menggunakan tenaga pemasar langsung, seperti agen asuransi, pialang saham, dan distributor yang berada di organisasi pemasaran langsung seperti produk herbalife, nuskin, oriflame. Selain itu juga bisa menggunakan cara lain, seperti telemarketing, online marketing, home shopping channel, dan sebagainya. Melalui bauran promosi yang sudah dijelaskan, komunikasi pemasaran memegang peranan yang sangat penting bagi pemasar dalam membentuk perilaku konsumen. 


\section{Pembahasan}

\section{Perubahan Perilaku Konsumen menuju Era Disrupsi}

Minat pembelian adalah penghubung utama dalam merangsang komunikasi dan hubungan antar individu. Banyak hobi berpusat pada produk atau layanan, seperti mengumpulkan perangko, modifikasi mobil, dan dekorasi rumah. Sebuah perusahaan yang menawarkan barang-barang terkait hobi berfungsi sebagai titik fokus bagi orangorang dengan minat yang sama untuk berinteraksi (Tauber, 1972). Keputusan untuk berbelanja akan terjadi ketika kebutuhan seseorang akan barang tertentu menjadi sangat kuat baginya untuk mengalokasikan waktu, uang, dan upaya untuk mengunjungi sebuah toko.

Gambar 3. Perkembangan pemasaran 1,0 - 4,0

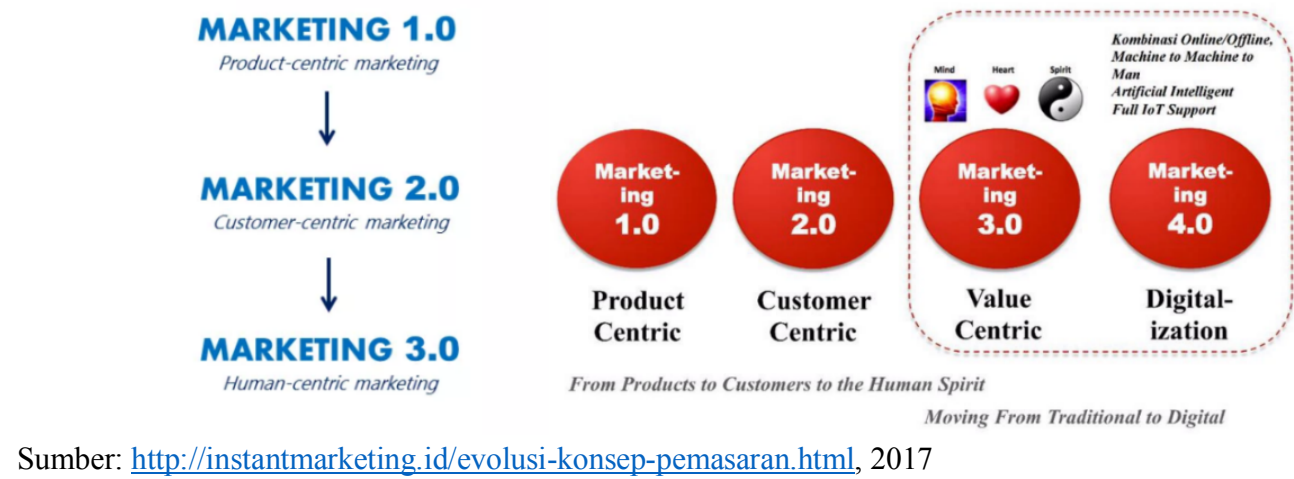

Konsep pemasaran 1,0 yang memperkenalkan pada pemasaran berbasis produk merupakan bagian sentral dari pemasaran layanan didasarkan pada kenyataan bahwa konsumsi layanan adalah konsumsi proses daripada konsumsi hasil, di mana konsumen atau pengguna menganggap proses produksi sebagai bagian dari konsumsi layanan, bukan hanya hasil dari proses itu seperti dalam pemasaran barang fisik secara tradisional (Grönroos, 1998). Saat perusahaan masih memonopoli pasar, menjadi produsen tunggal bagi seluruh konsumen, maka fokus mereka hanyalah efisiensi proses produksi. Perhatian utama perusahaan lebih banyak ditujukan pada pengembangan produk. Peran komunikasi pemasaran terhadap perilaku konsumen di era pemasaran 1,0 ini lebih banyak menawarkan kualitas dari produk itu sendiri. Misalnya perusahaan asuransi menawarkan produknya melalui pemasaran langsung yang dilakukan oleh agen penjualannya. Ketika mendapat kesempatan untuk bertemu, disini agen penjuak tersebut akan memberikan informasi mengenai produk yang disesuaikan dengan anggaran dan kebutuhan nasabah, juga tentang kekuatan dan kelebihan produk dan perusahaannya, penempatan dana nasabah, resiko dan sebagainya sehingga konsumen yang mungkin awalnya anti terhadap asuransi karena komunikasi yang baik bisa mulai membuka diri, walaupun mungkin tidak langsung terjadi sales, tapi setelah konsumen tahu, kemungkinan ia akan semakin tertarik, dan pada akhirnya akan memakai asuransi tersebut. Selain itu melalui tayangan iklan yang selalu membanjiri televisi, juga berperan sebagai media untuk berpromosi bagi perusahaan. Durasi iklan sangatlah singkat, oleh karena itu biasanya hanya berisikan tentang keutamaan produk, dan 
dengan tampilan iklan yang menarik biasanya konsumen akan terbujuk untuk melakukan pembelian. Terutama konsumen pada usia anak-anak mudah sekali terpengaruh oleh iklan. Stimuli untuk mengetahui perilaku konsumen di era ini menggunakan pendekatan yang benar-benar intens agar berakhir pada pengambilan keputusan pembelian.

Bergerak menuju revolusi pemasaran 2,0 yang ditandai dengan pemasaran berbasis pelanggan ini menggunakan komunikasi pemasaran terpadu. Komunikasi pemasaran terpadu adalah proses pengembangan dan pengendalian secara strategis atau mempengaruhi semua pesan yang digunakan untuk membangun dan memelihara hubungan dengan pelanggan dan pemangku kepentingan lainnya (Duncan, 1993 dalam Hutton, 1996). Komunikasi pemasaran terpadu ini juga tidak jauh dari perkembangan industri yang inovatif. Integrasi atau terpadu merupakan upaya untuk menyajikan pesan yang konsisten di seluruh elemen bauran promosi yang tersedia dan selalu penting bagi organisasi yang sukses bahkan selama pertengahan abad kedua puluh (Kitchen dan Burgmann, 2010). Dengan adanya perkembangan teknologi yang cepat dapat mempengaruhi komunikasi pemasaran terpadu dari dua sisi, yaitu dari sudut pandang pemasaran dan konsumen. Saat ini, integrasi diperlukan karena globalisasi dan saling ketergantungan yang dihasilkan antara negara dan pasar. Komunikasi yang dirancang idealnya terpadu dengan strategi bauran pemasaran lain yang dirumuskan perusahaan. Komunikasi pemasaran akan berhasil bila didukung oleh strategi produk, strategi harga dan strategi distribusi yang konsisten dengan kesan yang akan dibentuk. Jika pesan yang disampaikan bahwa produk ini memiliki kualitas tinggi, maka produknya juga harus benar-benar memiliki kualitas tinggi, tidak dijual disembarang tempat, sehingga konsumen tidak merasa dibohongi, jika konsumen sudah percaya maka ia akan mengkonsumsi produk tersebut. Dengan proses komunikasi pemasaran terpadu, interaksi dengan konsumen di era pemasaran 2,0 ini mengarah pada one-to-one relationship.

Perkembangan pemasaran 3,0 yang ditandai dengan pemasaran berbasis human ini memiliki pandangan nilai pada manfaat fungsional, manfaat emosional dan manfaat sosial. Para pemasar harus bisa menciptakan perubahan positif menurut pandangan konsumen, serta perusahaan bisa menginterpertasikan visi, misi dan nilai-nilai perusahaan dalam menciptakan produk agar sampai kepada konsumen dan dapat diterima oleh pasar. Di era ini perusahaan juga harus mengetahui bahwa pasar yang dilihat sudah masuk ke dalam kategori konsumen yang memiliki pikiran, hati dan semangat yang utuh. Pemasaran berbasis manusia ini memiliki peran komunikasi pemasaran dengan tujuan untuk membedakan (differentiating) produk yang ditawarkan perusahaan dengan produk lainnya. Differensiasi produk juga berkaitan dengan posisioning. Upaya membedakan produk ini dilakukan dengan mengkomunikasikan kepada konsumen tentang perbedaan produk, bisa dari segi fisik, isi, komposisi kandungan, harga, dan sebagainya. Melalui proses komunikasi pemasaran yang bertujuan membedakan produk untuk ditawarkan, maka interaksi dengan konsumen di era pemasaran 3,0 mengarah pada many-to-many collaboration. 
Perkembangan pemasaran yang memasuki era pemasaran 4,0 ini dibuktikan dengan perubahan teknologi yang cepat dan dengan kemunculan kombinasi online atau offline serta machine to machine, artificial intelligent, dan full IoT support. Pemasar dan konsumen saat ini memperluas komunikasi mereka melalui media baru yang dinamis yang disebut jejaring sosial. Komunikasi pemasaran dengan promosi itu yang paling efektif di media sosial, karena di era digital ini pemasaran berbasis tujuan sosial, mayoritas konsumen lebih tertarik untuk mencari informasi melalui telepon pintarnya masing-masing. Promosi melalui sosial media saat ini tengah banyak diminati oleh perusahaan-perusahaan yang memang mencari pasarnya melalui online antara lain instagram, facebook, atau whatsapp, dan lain sebagainya. Media sosial telah memperkuat kekuatan percakapan konsumen-ke-konsumen di pasar dengan memungkinkan satu orang untuk berkomunikasi dengan ratusan atau ribuan konsumen lain secara cepat dan dengan sedikit usaha. Namun, manajer tidak dapat langsung mengontrol proses tersebut, di sisi lain era pemasaraan 4,0 ini banyak pengguna yang senang berbelanja online melalui web atau smartphone. Manajer harus memahami bagaimana perilaku konsumen di era digital saat ini (Mangold dan Faulds, 2009). Hal ini merupakan perkembangan terbaru dalam produk iklan dan berkomunikasi dengan konsumen. Menurut Akar dan Topcu (2011), facebook adalah salah satu media sosial yang tumbuh paling cepat, yang mencakup curah pendapat spontan yang sangat besar di antara anggota jaringannya untuk mengembangkan pendapat. Faktanya, platform media sosial yang kuat telah menciptakan ruang lingkup teladan bagi merek apa pun untuk mengiklankan produknya melalui paparan, perhatian, dan persepsi; untuk mengembangkan opini; dan untuk menciptakan nilai-nilai (Kim dan Ko, 2012).

Penggunaan komunikasi satu arah (tradisional) untuk mempromosikan persepsi konsumen dan meningkatkan sikap positif terhadap nilai produk telah secara dramatis kehilangan pengaruhnya yang persuasif karena daya tarik Facebook yang luas sebagai metode koneksi untuk teman sebaya (Akar dan Topcu, 2011). Saat ini penilaian produk, evaluasi dan persepsi dan proses pengembangan sikap akhir telah secara drastis selaras dengan pola baru komunikasi multidimensi di mana konsumen lebih tertarik dan menemukan kredibilitas lebih melalui mengejar dan merampingkan pendapat yang mengintip daripada mendapatkan iklan pemasaran tradisional (Algharabat, AlAlwan, Rana, dan Dwivedi, 2017). Koufaris (2014) mengungkapkan bahwa respons emosional dan kognitif terhadap pengalaman berbelanja di web dapat mempengaruhi perilaku konsumen online, khususnya niat untuk kembali dan pembelian yang tidak direncanakan untuk pelanggan baru. Melihat konsumen online baik sebagai pembelanja maupun pengguna komputer, dengan memadukan paradigma teoretis dari psikologi, pemasaran, dan sistem informasi, kami mengkonfirmasi sifat ganda konsumen online sebagai pembelanja tradisional dan pengguna komputer. Hasil penelitian menunjukkan bahwa kenikmatan pengalaman berbelanja (variabel psikologis atau pemasaran) dan manfaat yang dirasakan dari situs web penting bagi niat pelanggan baru untuk kembali (Koufaris, 2014). 


\section{Simpulan}

Konsep komunikas pemasaran merupakan bentuk komunikasi yang bertujuan untuk memperkuat strategi pemasaran, guna meraih segmentasi yang lebih luas. Artikel ini dapat juga dikatakan sebagai upaya untuk memperkuat loyalitas pelanggan terhadap produk, yaitu barang dan jasa yang dimiliki perusahaan. Hal yang perlu dipahami oleh seorang pemasar adalah keberhasilan sebuah strategi komunikasi pemasaran dapat diukur dengan seberapa besar penjualan sebuah produk atau penghasilan dari pemanfaatan jasa oleh konsumen.

Berdasarkan penjelasan di atas dapat ditarik kesimpulan bahwa tanpa komunikasi, konsumen maupun masyarakat secara keseluruhan tidak akan mengetahui keberadaan produk di pasar, jika tidak tahu bagaimana mungkin akan melakukan pembelian. Sebaliknya dengan komunikasi, dimana produsen atau perusahaan akan melakukan pemilihan terhadap media apa yang akan digunakan, bagaimana mengemas pesan tentang produk dan perusahaannya, siapa sasarannya dan siapa yang akan menjadi narasumber ketika akan menginformasikan produk, semua hal yang terkait dengan pemasaran akan menjadi lebih efektif, jika pemasaran sudah tepat sasaran, tentu saja perilaku konsumen yang diharapkan akan terwujud. Agar memiliki tingkat loyalitas yang tinggi dalam pembentukan sikap dan perilaku konsumen, maka karakteristik pesan harus lebih kuat dengan penguatan citra merek dan citra produsen.

Di sisi lain, alat-alat komunikasi pemasaran bisa berupa iklan, tenaga penjualan, papan nama, toko, display, kemasan produk, sampel produk gratis, kupon, giveaway dan lainnya. Adapun perubahan perilaku konsumen yang semakin berkembang, dampak dari pemasaran 4,0 juga menghasilkan adanya pemasaran viral melalui jejaring sosial seperti Facebook memungkinkan interaktivitas dua arah secara terus-menerus dari mana saja dan kapan saja. Saat ini diperlakukan sebagai saluran alternatif yang kuat dan ada di mana-mana untuk memberikan informasi. Selain itu, pemasaran viral juga bisa melalui influencer mikro yang saat ini banyak digunakan oleh usaha kecil menengah untuk menaikan produknya di pasar melalui melalui media sosial karena mayoritas pasar saat ini di isi oleh gen milenial dan gen z yang sangat maju akan teknologi.

Isi suatu pesan dalam pemasaran sangat mempengaruhi konsumen dalam menilai suatu produk. Oleh karena itu, komunikator harus bisa membuat pesan yang efektif. Idelanya pesan tersebut harus menarik perhatian, menimbulkan minat, memicu keinginan, dan mendorong orang untuk membeli produk tersebut. Perlunya mengetahui perubahan perilaku konsumen menuju era disrupsi ini juga menjadi bahasan utama yang diperlukan oleh seorang pemasar agar bisa mengikuti ritme perubahan konsumen yang sangat beragam.

\section{Daftar Pustaka}

Akar, E., \& Topcu, B. (2011). An examination of the factors influencing consumer's attitudes toward social media marketing. J. Internet Commer., 35-67.

Algharabat, R., AlAlwan, A., Rana, N., \& Dwivedi, Y. (2017). Three dimensional product presentation quality antecedents and their consequences for online retailers: the moderating role of virtual product experience. J. Retail. Consum. Serv., 203-217. 
Ball, A., \& Tasaki, L. H. (1992). The Role and Measurement of Attachment in Consumer Behavior. Journal of Consumer Psychology, 155-172.

Ball, D., Simoes, P., \& Machas, A. (2004). The Role of Communication and trust in explaining customer loyalty: An extension to the ECSI model. European Journal of Marketing, 12721293.

Dharmesta, B. S., \& Handoko, T. H. (2016). Manajemen Pemasaran: Analisis Perilaku Konsumen. Yogyakarta: BPFE UGM.

Duncan, T., \& Moriarty, S. E. (1998). A Communication-Based Marketing Model for Managing Relationship . Journal of Marketing, 1-13.

Grönroos, C. (1998). Marketing services: the case of a missing product. JOURNAL OF BUSINESS \& INDUSTRIAL MARKETING, 322-338.

Gupta, R. (2016). Disruptive Marketing and Brand Building-A Case Study of Patanjali, Ayurveda Limited. Advances in Economics and Business Management (AEBM), 225-231.

Howard, J. A., \& Sheth, J. N. (1967). A Theory of Buyer Behavior. Changing Marketing Systems Consumer, Corporate and Goverment Interfaces: Procedings of the 1967 Winter Conference of the American Marketing Association, 137-155.

Hutton, J. (1996). Integrated Marketing Communication and The Evolution of Marketing Though. Journal of Business, 155-162.

Kasali, R. (2008). Disruption. Jakarta: PT. Gramedia Pustaka Utama.

Kim, A., \& Ko, E. (2012). Do social media marketing activities enhance customer equity? An empirical study of luxury fashion brand. J. Bus. Res., 1480-1486.

Kitchen, P. J., \& Burgmann, I. (2010). Integrated Marketing Channel. Wiley International Encyclopedia of Marketing, 1-23.

Komala, L. (2009). Ilmu Komunikasi : Perspektif, Proses dan Konteks. Bandung: Widya Pajajaran.

Kotler, P., \& Armstrong, G. (2018). Principles of Marketing (7th ed.). United Kingdom: Pearson.

Kotler, P., \& Keller, K. L. (2016). Marketing Management Global Edition (15th ed.). United States of America: Pearson Education Limited.

Kotler, P., Kartajaya, H., \& Setiawan, I. (2016). Marketing 4.0: Moving from Traditional to Digital. Canada: John Wiley \& Sons Inc., Hoboken, New Jersey.

Koufaris, M. (2014). Applying the Technology Acceptance Model and Flow Theory to Online Consumer Behavior. Information Systems Research, 205-223.

Loudon, D. L., \& Bitta, A. D. (1993). Consumer Behavior: Concept and Applications. The United State of America: By McGraw Hill Inc.

Mangkunegara, A. P. (2015). Perilaku Konsumen. Bandung: Refika Aditama.

Mangold, W., \& Faulds, D. (2009). Social media: The new hybrid element of the promotion mix. Business Horizons Elsevier, 357-365.

Mohir, L. A., Webb, D. J., \& Harris, K. E. (2001). Do Consumers Expect Companies to be Socially Responsible? The Impact of Corporate Social Responsibility on Buying Behavior . The Journal of Consumer Affairs, 45-72.

Pavenkov, O. V., \& Rubtcova, M. V. (2019). Traditional model of marketing communications and integrated marketing communications: comparative research. ITM International Conference and Summit on Techno Management Trends.

Seric, M., Ozretic-Dosen, D., \& Skare, V. (2019). How can perceived consistency in marketing communications influence customer-brand relationship outcomes? European Management Journal, 1-9.

Shimp, T. A. (2000). Periklanan Promosi: Aspek Tambahan Komunikasi Pemasaran Terpadu (5nd ed.). Jakarta: Erlangga.

Soemanagara, R. (2012). Strategic Marketing Communication: Konsep Strategis dan Terapan. Bandung: Alfabeta.

Swastha, B., \& Irawan. (2008). Manajemen Pemasaran Modern. Yogyakarta: Liberty Yogyakarta.

Tauber, E. M. (1972). Marketing Notes and Communications. Journal of Marketing, 46-59.

Webster Jr., E. F., \& Wind, Y. (1972). A General Model for Understanding Organizational Buying Behavior. Journal of Marketing, 12-19. 
Xie, B.-C., Shang, L.-F., Yang, S.-B., \& Yi, B.-W. (2014). Dynamic environmental efficiency evaluation of electric power industries: Evidence from OECD (Organization for Economic Cooperation and Development) and BRIC (Brazil, Russia, India and China) countries. Energy, 147-157. 